\title{
Knowledge Differences, Attitudes and Practices Using Six Thinking Hats by Gender and Specialization in the Malay Language Primary School Teachers
}

\author{
Zamri Mahamod, Mohd Qhairil Anwar Azhar, Hadi Hassan \\ Faculty of Education, University Kebangsaan Malaysia, Bangi, Malaysia \\ Email: d-zam@ukm.edu.my
}

How to cite this paper: Mahamod, Z., Azhar, M. Q. A., \& Hassan, H. (2019). Knowledge Differences, Attitudes and Practices Using Six Thinking Hats by Gender and Specialization in the Malay Language Primary School Teachers. Creative Education, 10, 2186-2200.

https://doi.org/10.4236/ce.2019.1010158

Received: July 24, 2019

Accepted: October 20, 2019

Published: October 23, 2019

Copyright $\odot 2019$ by author(s) and Scientific Research Publishing Inc. This work is licensed under the Creative Commons Attribution International License (CC BY 4.0).

http://creativecommons.org/licenses/by/4.0/

\begin{abstract}
The purpose of this study is to identify the difference in the Six Thinking Hats based on gender and specialization among Malay Language primary school teachers. This survey was conducted on all primary language primary school teachers in the Sentul Zone Education Office, Federal Territory of Kuala Lumpur. A total of 36 national schools became the population for this study, involving a total of 210 teachers. The sample selection was based on the sample size determinants of Krejcie and Morgan studies. Through the sample size determinants, the sample states if the total population is 210 people, the sample is 136 people. The questionnaire was used to measure the aspects related to the level of knowledge, attitude and practice of using Six Thinking Hats ideas among Malay Language primary school teachers. Questionnaires use five Likert scales. A pilot study was conducted on 18 Malay language teachers from two national schools. The data were analyzed using Statistical Packages for Social Societies (SPSS) Statistics version 23. This study uses two types of analysis, namely descriptive analysis and inferential analysis. The findings show that the level of knowledge and attitude of Malay Language teachers in the use of Six Thinking Hats as the means of thinking in teaching and learning are at a high level. The level of practice of Malay Language teachers in using Six Thinking Hats ideas was at moderate level. The implication of this study is that the use of Six Thinking Hats in the teaching and learning of Malay Language can increase the interest and achievement of the students.
\end{abstract}

\section{Keywords}

Knowledge, Attitude, Usage of Practice, Six Thinking Hats, Gender, Specialization 


\section{Introduction}

Every individual has the ability to develop the mind to become more brilliant regardless of whether the individual is five or 95 years old (Minirith, 2009). In line with the sixth challenge of Vision 2020, the nation intends to create a scientific and progressive society, a community with high-power and forward-looking people who are not only technologists but also contribute to future scientific and technological developments. One that is done by the KPM is to introduce six thought tools. One of them is six hat ideas. Malaysia Ministry of Education (MoE) has made several plans and strategies to overcome this problem, among others, by introducing the six-hat method of thinking through higher order thinking skills (HOTS). Implementation of the six-hat concept in school was introduced to enhance and empower students' thinking skills. This method was created by Edward de Bono, a leading Western thinker and writer. This parallel thinking method is intended to broaden perspective, look at things from different angles and times, solve problems and make the best decisions. Thinking parallel means thinking in parallel, orderly and systematicaly. For example, six different ideas are accepted and placed in parallel with each other and are not comparable, disputed, and are not proved to be true or false, otherwise sought after by each other.

\subsection{Six Topics of Thinking}

These six thinking hats have been introduced by Edward de Bono (1991), a leading Western thinker and writer. This parallel thinking method is intended to broaden perspective, look at things from different angles and times, solve problems and make the best decisions. Through these six hats of thought, every thought is analogous to a hat with certain colors, namely white, red, black, yellow, green and blue. The description of the meaning of each hat color is as follows:

1) The white hat symbolizes neutral and objective thinking that emphasizes objective facts and matters solely.

2) The red hat also symbolizes emotional thinking and based on feelings and intuition.

3) The black hat represents a negative thought that emphasizes disadvantages, weaknesses and disabilities.

4) The yellow hat represents a positive thought that uses goodness, privilege and benefit.

5) The green hat symbolizes creative thinking and thus generates new ideas that are brilliant or develop existing ideas, either logically or vice versa.

6) The blue hat symbolizes the control of the control and therefore controls the travel of a matter including other hats.

According to Said et al. (2013), the education system again believes that thinking skills should be mastered properly and comprehensively if they want to become a developed nation of Korea and Japan. The Sixth Hats of Thought is one of the thinking skills programs that teachers can implement in embracing and embracing HOTS among students in school. 


\subsection{Statement of Problems}

Implementation of the New Lower School Curriculum (KBSR) in 1983 and the Secondary School Integrated Curriculum (KBSM) in 1989 has demanded some changes in the curriculum development, teaching education, the use of teaching and learning strategies, and school administration. In this context, an initiative was introduced by the MOE, a program of critical thinking and creative thinking in the process of teaching and learning. The 2013-2025 Education Development Plan (MoE, 2013) has also translated into the goal of the National Education Philosophy that is planning a balanced education as the basis of achieving student aspirations through six elements in which one is thinking skills.

Accordingly, the MoE introduced the six-cap method of thought created by de Bono (1991). Knowledge of thinking skills in the teaching and learning process among teachers is still low. This is indirectly a related problem in this study which involves aspects of teacher knowledge. This issue was in line with the statement by Hasan \& Mahamod (2016), which found that the Malay Language teachers were still unable to integrate KBAT in the teaching and learning process.

Most teachers are still unclear and vague about the appropriate methods to apply thinking skills in the teaching and learning process in the classroom. In essence, various efforts have been undertaken by the MoE to encourage teachers to introduce thinking skills to students in schools for example by giving exposure on thinking skills through courses organized by Curriculum Development Centre (CDC) or in-house courses by the school. The Malay teachers should understand the concept of HOTS to ensure the effectiveness of teaching and learning goes smoothly. Most of the teachers are still in the notch where teachers are less stimulating students towards KBAT thinking in schools (Rahman \& Mahamod, 2016).

Teachers also use six thought caps as thinking tools in HOTS. This is a problem with the difficulty of shifting from traditional instruction to student-centered teaching as students are still relying on text-based teaching methods. This statement can be demonstrated through Stegall's study (Stegall, 2011), saying that most teachers use traditional patterns of teaching that can influence the level of teacher's emotional self-esteem. Teaching and learning used by teachers are still in the form of "chalk and talk" and teachers are less diversifying teaching methods and techniques that can stimulate students' thinking skills in the process of teaching and learning in schools.

The research conducted by Mohamat (2016), found that most teachers deliver more knowledge based on content and self-centered teaching. This is due to the fact that teachers are too pursuing excellence and student-based performance exclusively. Thus, the learning process takes place on a baseline basis and does not concern the overall comprehension of the students. Academic achievement at the primary education level is an indicator and serves to reflect the reach of academic achievement at a higher level. Therefore, teachers lack emphasis on the 
essential skills in the teaching and learning process in the classroom.

According to Lewis \& Smith (2002), they use more than 70 percent of the type of questions they remember during their teaching. Teachers also emphasize on factual questions in tests and examinations. This causes the teaching and learning process to lessen students' thinking skills. Anderson \& Krathwol (2001), the term used to think at the high level itself is to analyze, evaluate and create. Therefore, teachers should be prepared and have a high level of knowledge in implementing the method of thinking skills among students. Teachers need to diversify teaching methods to improve students "thinking skills in schools so that they can influence and stimulate students" interest in learning.

The HOTS study specifically on the I-Think thinking map has been carried out in Malay Language subjects. However, the study of the six-cap method of thinking among Malay Language teachers has not been studied by any researcher.

\section{Objectives of the Study}

The purpose of this study is to evaluate the level of knowledge, attitude and practice of using six gender-based thinking skills and topics among national language teachers. Specifically, the objective of this study is to:

1) Identify the different level of knowledge, attitude and practice of the Six Hats of Thought among national language teachers of the national school-based on gender.

2) Identify the different levels of knowledge, attitudes and practices of Six Hats of Thought among national language teachers of national schools based on specialization.

\section{Study Questions}

Specifically, some research questions have been developed so that the purpose of this study is achieved. The question of the study is as follows:

1) What is the level of knowledge of the use of Six Hats of Thought among national school Malay teachers?

2) What is the level of attitude of use of Six Hats of Thought among national language teachers of Malay schools?

3) What is the level of practice of using Six Hats of Thought among national school Malay teachers?

4) Is there a difference in the level of knowledge of the use of Six Hats of Thought among national language teachers of the national school-based on sex?

5) Is there a difference in the attitudes of the use of Six Hats of Thought among national language teachers of the national school-based on sex?

6) Is there a difference in the practice of using Six Hats of Thought among national language teachers of the national school-based on sex?

7) Is there a difference in the level of knowledge of the use of Six Hats of Thoughts among national language teachers of Malay language based on specia- 
lization?

8) Is there a difference in the attitudes of the use of Six Hats of Thought among national language teachers of the national language based on specialization?

9) Is there a difference in the level of practice of using Six Hats of Thought among national language teachers of Malay based on specialization?

\section{Methodology}

\subsection{Research Design}

The study uses survey method. The design of the survey was chosen because it was appropriate to be administered on the sample within a limited time. The survey method was used to obtain information on the level of knowledge, attitudes and practices of the use of six brain storming amongst national language teachers. A set of questionnaire instrument is used for data collection purposes.

\subsection{Respondent}

Respondents' study is all national language teachers in the Sentul Zone Education Office (PPZS), Federal Territory of Kuala Lumpur. A total of 36 national schools became the population for this study, involving a total of 210 teachers (JPZS data, WPKL 2017). The sample of this study was 136 people. The sample selection was based on the sample size determinants of Krejcie \& Morgan (1970). Through the table of determinants the sample states that if the total population is 210 people, then the sample is 136 people.

\subsection{Instrument}

Instruments the questionnaire instrument was used in this study. The questionnaire was used to measure aspects related to the level of knowledge, attitudes and practices of the use of six brain storming amongst national language teachers. The set of questionnaire consists of four sections. All instruments are modified from the study (Mohamt, 2016). Questionnaires use five Likert scales. According to Abu Bakar Nordin (1995) the Likert scale was chosen because of the high reliability value and also gave the respondent the opportunity to make the right choice based on the degree of acceptance of the respondent. The Likert scale is the lowest level, while the five highest scales.

\subsection{Pilot Study}

The study was conducted on 18 Malay language teachers in two national schools. The data obtained will be analyzed using Statistical Packages for the Social Sciences (SPSS) Statistics version 22. SPSS to determine the reliability value of the Cronbach alpha. In the pilot study, each item obtains an alpha value which is at a good level and is very good or high above 0.80 . The results of the pilot study showed that the alpha value for the readiness of the construct was 0.874 , the attitude construct was 0.935 and the construct of practice was 0.846 . The total 
number of alpha Cronbach is 0.885. According to Tasir \& Abu (2003), Alpha values between 0.60 and 0.80 are accepted, while alpha values above 0.80 are considered good. This means that the constructs of the study have reliable reliability.

\subsection{Data Analysis}

This study uses two types of analysis, namely descriptive analysis and inference analysis. Descriptive analysis and percentages are used to determine the level of knowledge, attitude and practice of teachers towards the use of six hat ideas. In addition, practice analysis based on frequency of material usage and percentage was also used to see respondents' background distribution. Mean range interpretation is made according to the scale used by Moidunny (2009) (Table 1).

An independent t-test analysis was conducted to identify the difference in mean values. In this study, independent t-test analysis was conducted to identify the differences in knowledge, attitude and practice of Malay language teachers on the use of six subject-based thinking skills and teachers' specialties. The Pearson correlation test is used to test the null hypothesis related to the relationship. The Pearson correlation test is used to see the relationship between the data in the form of interlaced and the relationship with the variable is linear.

\section{Research Fundings}

\section{Respondent Profile}

Sample of this study consists of 136 Malay teachers from 36 national schools in the Sentul area, Federal Territory of Kuala Lumpur. Table 2 describes in more detail the demographics of the survey respondents obtained from the questionnaire. Conclusion that can be made is that more female teachers than male teachers, most experienced teachers teach between 4-10 years, 92.6 Malay teachers are teachers before the Bachelor's Degree, $82.4 \%$ of teachers are Malay language teachers and most teachers teach level 1 and 2. In other words, all Malay language teachers are experienced teachers in the field.

Knowledge Level Difference Using Six Hats of Thought in Teacher of Malay Language National School by Sex

Table 3 shows that there is no significant difference in the level of knowledge of the use of six brain storming among the national school teachers in Indonesia

Table 1. Mean range to answer the question of testing the t-test is independent.

\begin{tabular}{cc}
\hline Mean Min Score & Interpretation \\
\hline 1.0 to & 1.8 Very low \\
1.9 to & 2.6 Low \\
2.7 to & 3.4 Medium \\
3.5 to & 4.2 Height \\
4.3 to & 5.0 Very high \\
\hline
\end{tabular}


Table 2. Demographic analysis respondents.

\begin{tabular}{|c|c|c|}
\hline Demographic & Frequency & Percentage (\%) \\
\hline \multicolumn{3}{|l|}{ Gender } \\
\hline - Male & 47 & 34.6 \\
\hline - Female & 89 & 65.4 \\
\hline \multicolumn{3}{|l|}{ Age } \\
\hline - 23 - 26 years & 15 & 11.0 \\
\hline - 27 - 35 years & 69 & 50.7 \\
\hline - 36 - 40 years & 23 & 16.9 \\
\hline - 41 years and above & 29 & 21.3 \\
\hline \multicolumn{3}{|c|}{ Experience Teaching Bahasa Melayu } \\
\hline - 1 - 3 years & 27 & 19.9 \\
\hline . 4 - 5 years & 70 & 51.5 \\
\hline - $11-19$ years & 25 & 18.4 \\
\hline . 20 years and over & 14 & 10.3 \\
\hline \multicolumn{3}{|c|}{ Academic Qualifications } \\
\hline - Diploma of Education & 3 & 2.2 \\
\hline - Bachelor's & 126 & 92.6 \\
\hline - Degree & 7 & 5.1 \\
\hline \multicolumn{3}{|c|}{ Master's Specialization Language } \\
\hline - Yes & 112 & 82.4 \\
\hline - No & 24 & 17.6 \\
\hline \multicolumn{3}{|c|}{ Teaching Class Level } \\
\hline - Level 1 & 64 & 47.1 \\
\hline · $\quad$ Level 2 & 62 & 45.6 \\
\hline - Level 1 and Level 2 & 10 & 7.4 \\
\hline
\end{tabular}

Table 3. The difference in the level of knowledge of the use of six brain storming among the teachers of the national language teachers by gender.

\begin{tabular}{ccccccc}
\hline Gender & N & Min & Deviation Standard & t & df & Sig. \\
\hline Male & 47 & 3.75 & 0.644 & & & \\
Female & 89 & 3.56 & 0.546 & 1.768 & 134 & 0.079 \\
\hline
\end{tabular}

${ }^{*} p>0.005$.

based on sex with $\mathrm{t}=1.768$ and $\operatorname{sig}=0.079(p>0.05)$. In terms of mean value, male teachers $(\min =3.75$ and $\mathrm{SP}=0.644)$ recorded a higher level of attitude of using six higher thinking capes than female teachers ( $\min =3.56$ and $\mathrm{SP}=$ 0.546). However, the null hypothesis (H01) does not mean that there is no significant difference in the level of knowledge of the use of six brainstorming among the national language teachers of the national school-based on gender has failed to be rejected due to sig value $=0.079(p>0.05)$. 
In other words, the level of knowledge of the use of six brain storming amongst national language teachers is not influenced by gender. Malay language teachers and teachers have a high level of knowledge about the use of six thought maps in Malay language teaching and learning. Teachers of boys and girls know how to use six thought maps as an effective and instructional teaching tool for students to learn Malay in the classroom.

Level of Attitude Differences Using Six Hats of Thought in Teacher of National Language Teacher of National School by Sex

Table 4 shows that there is no significant difference in the level of the attitude of the use of six hats of thinking among national language teachers of the national school-based on sex with $\mathrm{t}=1.668$ and sig $=0.098(p>0.05)$. When viewed from the mean value, male teachers ( $\min =3.72$ and $S P=0.260$ ) recorded a higher level of attitude towards the use of six higher thinking capes than female teachers (mean $=3.61$ and $S P=0.428)$.

However, the null hypothesis (H02) shows that there is no significant difference in the attitudes of the use of the six-cap of thinking among the national language teachers of the national school-based on gender is rejected due to the sig value $=0.098(p>0.05)$. Therefore, the findings of the study find out that the level of attitude of the use of Six Hats of Thought among the national language teachers is not influenced by gender.

Difference of Knowledge Level Using Six Hats of Thought in Teacher of Malay Language National School based on Specialization

Table 5 shows that there is a significant difference in the level of knowledge of the use of Six Hats of Thought among national language teachers of the national schools based on the specialization of $\mathrm{t}=2.546$ and sig $=0.012(p<0.05)$. In view of the mean value, the teachers of Malay language specialization $(\mathrm{min}=$ 3.69 and $\mathrm{SP}=0.557$ ) recorded a higher level of knowledge of the use of Six Higher Thoughts than the non-Malay language teachers (mean $=3.36$ and $\mathrm{SP}=$ 0.652).

This indirectly shows the null hypothesis (H04) that there is no significant difference in the level of knowledge of the use of Six Hats of Thought among national language teachers of the national language based on specialization is rejected. The findings of the findings also explain that the level of knowledge of the use of Six Hats of Thought among the teachers of the national language schools is influenced by the specialization of the teacher.

Difference Attitude Levels Using the Six Hats Thinking in Circles Malay National School Teachers by Specialization

Table 6 shows that there is no significant difference in the attitudes of the usage of Six Hats of Thought among the national language teachers of teachers based on the specialization of $t=1.701$ and $\operatorname{sig}=0.091(p>0.05)$. In view of the mean value, the Malay language specialists $(\mathrm{min}=3.67$ and $\mathrm{SP}=0.366)$ recorded the higher level of attitude towards the use of Six Higher Thoughts than non-Malay teachers $(\min =3.53$ and $\mathrm{SP}=0.437)$. 
Table 4. The t-test does not rely on the difference in the level of attitude of use of Six Hats of Thought among national language teachers of national schools based on gender.

\begin{tabular}{ccccccc}
\hline Gender & $\mathrm{N}$ & Min & Deviation Standard & $\mathbf{t}$ & $\mathrm{df}$ & Sig. \\
\hline Male & 47 & 3.72 & 0.260 & & & \\
Female & 89 & 3.61 & 0.428 & 1.688 & 134 & 0.098 \\
\hline
\end{tabular}

${ }^{*} p>0.005$.

Table 5. T-test does not depend on the level of knowledge usage of the Six Hats of Thought among national language teachers of the national schools based on specialization.

\begin{tabular}{ccccccc}
\hline Specialization & $\mathbf{N}$ & Min & Deviation Standard & $\mathbf{t}$ & df & Sig. \\
\hline Option & 112 & 3.69 & 0.557 & & & \\
No option & 24 & 3.36 & 0.652 & 2.546 & 134 & 0.012 \\
\hline
\end{tabular}

${ }^{*} p>0.005$.

Table 6. T-test does not depend on the difference in the level of attitude of use of Six Hats of Thought among national language teachers of national schools based on specialization.

\begin{tabular}{ccccccc}
\hline Specialization & $\mathbf{N}$ & Min & Deviation Standard & $\mathbf{t}$ & df & Sig. \\
\hline Option & 112 & 3.67 & 0.366 & & & \\
No option & 24 & 3.53 & 0.437 & 1.701 & 134 & 0.091 \\
\hline
\end{tabular}

${ }^{\star} p>0.005$.

This indirectly shows the null hypothesis (H05) that there is no significant difference in the level of attitudes towards the use of Six Hats of Thought among teachers of the national language schools based on the specialization is failed to be rejected. The findings of the study also explain that the level of attitude of the use of Six Hats of Thought among the national language teachers of the national school is not influenced by the teacher's proficiency.

Differences Using the Practice Level Six Thinking Hats in Circles Malay National School Teachers by Specialization

Table 7 shows that there is a significant difference in the practice level of the Six Hats of Thought among national language teachers of the national schools based on the specialization of $\mathrm{t}=5.345$ and sig $=0.00(p<0.05)$. In terms of mean value, the Malay language specialists $(\min =3.49$ and $\mathrm{SP}=0.465)$ recorded the higher level of practice of Six Higher Thoughts than non-Malay teachers (mean $=2.92$ and $\mathrm{SP}=0.527$ ).

This indirectly shows the null hypothesis (H06) that there is no significant difference in the practice of using the Six Hats of Thought among the national language teachers of the Malay language based on specialization is rejected. In addition, the findings of the study find out that the level of practice of using Six Hats of Thought among national language teachers is influenced by the specialization of the teacher. 
Table 7. The t-test does not rely on the difference in practice level of Six Hats of Thought among national language teachers of national schools based on specialization.

\begin{tabular}{ccccccc}
\hline Specialization & $\mathbf{N}$ & Min & Deviation Standard & $\mathbf{t}$ & df & Sig. \\
\hline Option & 112 & 3.49 & 0.465 & & & \\
No option & 24 & 2.92 & 0.527 & & & \\
\hline
\end{tabular}

${ }^{*} p>0.005$.

\section{Discussion}

\section{Knowledge Level of Use of Six Hats of Thought in Teacher of National Malay Language Teacher}

Based on descriptive statistical analysis, the level of knowledge of the use of six brain storming among the national language teachers of the national language gives the total value of mean 3.63 and the standard deviation of 0.69 . This indirectly indicates that the level of knowledge of the teacher is at a high level. This is because teachers have been through the In-Service Training (LADAP), seminars and courses that give a comprehensive exposure on the use of six thought caps because Six Hats of Thought is one of the tools in the HOTS.

Science is one of the most important aspects of the everyday life of the human being in doing daily tasks. There is no exception for a teacher in the effort to channel knowledge known to his students. A teacher should have a detailed knowledge of the subject taught or the method to be applied in the Teaching and Learning process. This statement is fully supported by Mahamod (2014) which states that teachers as curriculum translators in schools should have the knowledge, understanding and confidence in delivering instruction to students in order to achieve the planned teaching process. Before using the Six Hats Thinking method, teachers need to have prior knowledge about the Six Hats Thinking method, skills when implementing the Six Hats Thinking Methods in the subject taught and being positive towards the method to be implemented by giving the impression that such methods can help students understand the learning. This is because an effective teacher is a teacher who can give a positive view of the students to the subjects learned.

The findings of this study are also parallel to the previous researcher's findings such as the results of Siti Zaleha's study (Nor, 2015) which shows that the knowledge of teachers is at a high level. According to Mohamed (2006) and Puteh (2012), teachers need to know and be knowledgeable in their thinking skills especially in the Teaching and Learning process. The use of six thinking hats is one of the most effective thinking tools that can be adapted by teachers while in the classroom. This will enable teachers to improve their understanding of the subjects taught. However, the findings show that the level of knowledge of teachers is at a high level in contrast to the findings of the study (Aziz, 2011) which found that the level of knowledge of Malaysian teachers was at moderate to the innovation of the methods that existed this century. 
This is likely to occur because most of these methods are widely applied in the Science stream. Therefore, exposure to the latest methods that can help the teacher's teaching process and help students to be active in the Teaching and Learning process should be more effectively exposed to teachers. The knowledge of a teacher is meaningful so that teachers can utilize the use of six thinking hats in teaching.

The summary, in this study, has explained that the level of knowledge of teachers in the use of six thinking hats as thinking tools has been at a high level. This is because teachers have been exposed and introduced with 21st century learning (PAK 21) in Teaching and learning at school. Therefore, teachers need to continuously enhance and develop HOTS-shaped knowledge and engage in active involvement of students in the classroom. Indirectly, the knowledge level of teachers in the use of six thought caps is in line with the wishes of the KPM to produce productive generations.

The Attitude Level of Use of Six Hats of Thought in the National Teacher of the Malay Language School

Teacher attitude level was measured based on 12 questionnaire questionnaires. Based on the descriptive statistical analysis, the attitude of the use of Six Hats of Thought among national language teachers of the national school gave the total value of mean 3.65 and the standard deviation of 0.55 . This indirectly shows that the level of teacher's attitude is at a high level. This is because the subject teachers always have a positive attitude in optimizing the performance, knowledge and understanding of students in their learning in line with FPK's will.

The results of this study were supported by the findings of Isnon \& Badusah (2017), regarding the attitude of teachers towards KBAT at high levels. Given that Six Hats of Thought is one of the toolkit in HOTS indirectly the above statement of support is intact to use. Teachers who are always positive will also have a positive impact on student learning outcomes and disabilities. This statement is fully supported by the findings of Isa (2015) findings that teachers' positive attitudes towards approaches have links with the level of attitude and skill of the teacher. The findings of the level of attitude of the teachers were at high level as well as in line with Mahamod (2014) study which explained that success and excellence in a subject would not be a reality if the teaching of the teacher was still using the traditional method and did not account for the thinking skills aspect that was seen to influence the achievement of students.

Referring to Aziz (2011), attitude includes feelings, beliefs and thoughts that influence a person in giving value to a favored or disliking aspect. Attitude is a mental preparation that can influence one's reaction to something dynamically. Ahmad (2011) has divided the attitudes into three main components namely cognitive (ideas and beliefs), affective (feelings and tendencies) and behavior (actions and answers). The level of tendency of a person's behavior or attitudes that can be observed through response and behavior or attitude toward observa- 
tion of something is influenced by these three main components. The attitude of each individual to each other is different (Hassan, 2009).

The Hat of Thought among national language teachers of the national schools can be further enhanced even though the findings show that the level of teacher's attitudes is at high level by expanding the exposure of the use of Six Hats Thoughts in the field of education. Teachers and instructors can initiate studies and modify the suitability of the use of Six Hats Thought to their teaching process. In other words, the attitude of the Malay language teachers in the use of Six Hats of Thought is at a high level thus enhancing student understanding in Teaching and learning. This is due to the positive competitiveness among teachers to achieve excellent academic performance in schools. Therefore, teachers need to prepare themselves with excellent knowledge and attitudes to strengthen the quality of teaching in Teaching and learning.

The Level of Practice of Using Six Hats in the Thinking of the Teacher of the Malay National School

The level of teacher practice was measured based on 16 items of questionnaire. Based on the descriptive statistical analysis that has been implemented, the practice level of the Six Hats of Thought among the national language teachers of the Malay language gives the mean value of mean 3.39 and the standard deviation of 0.61 . This implies that the level of teacher practice is at a moderate level. This is due to the time constraints and the burden of duties beyond Teaching and the increasingly frequent learning that teachers have to bear. Practice is defined as practicing something learned and known with sincerity and execute it properly and perfectly (Abdullah, 2006). The practice level of the Six Hats of Thought was moderate in parallel with the findings of Sulaiman et al. (2012) found that over $60 \%$ of teachers practice HOTS practice.

Teachers were found to continue applying the use of Six Hats Thought in the Teaching and Learning process to increase student learning knowledge although the level of teacher practice was at moderate level. This is because the level of knowledge and the level of teacher attitude towards the use of Six Hats of Thought is high. Teachers need to master the level of practice of using methods because teachers play a role in educating individuals to better and evaluate students (Ahmad \& Mahamod, 2015). The results of this finding coincide with the findings of Ishak (2015) which state that the use of graphic and pictorial materials stimulates thinking, strengthens memory and facilitates student understanding.

Overall, through the use of Six Hats the teachers' mindset found that their use could improve the speaking and listening skills of the students more productively during the discussion of the learning topic. Teaching and learning process environments are also more fun and smooth. Therefore, this can make it easier for students to understand the contents of the teaching delivered by the teacher. In such a situation, this clearly proves that the practice of using Six Hats Thoughts is rational and thoughtful. 


\section{Research Implication}

The study has been supporting the importance and positive impacts on the education sector in Malaysia, especially the level of knowledge, attitude and practice of teachers during the teaching and learning process. The use of Six Hats Thought is one of the thinking tools for student-centered learning and promotes active positive student engagement as the teaching goals are based on HOTS. Teachers only serve as facilitators. This is indirect, in line with MoE aspiration to produce human capital that has the quality of HOTS and is capable of competing for the present generation of the world.

As an insightful educator, we should have an initiative to improve the level of knowledge, attitude and practice of teachers in the implementation of Teaching and learning among students so that their cognitive level can be effectively and best developed. The use of teaching methods plays an important role as every student with learning has different levels of abilities, achievements and tendencies. They also have different interpretations of opinions on the topic of learning that are being discussed with subject teachers. Consequently, the use of Six Hats of Thought in the Teaching and Learning process is relevant. Basically, indeed in firing HOTS against students will need a long time to become firm and intact. However, it is not supposed to be the reason for the teacher to ignore such teaching. The root of the knowledge, the level of knowledge, attitude and practice of the teacher itself in the use of one of the suggested thinking tools in PPPM such as Six Hats of thought became a benchmark in determining this success.

In addition, the findings of this study are expected to assist certain parties involved in the effort to further improve the implementation of thought tools such as the use of Six Hats of Thoughts in creating HOTS more widely. The results of this study can be adopted by the BPKKPM, JPWPKL and PPWS in an effort to draw on and make improvements in the implementation of the Six Useful Thought Thinking plan in order to help students improve the idea of raising ideas, opinions and arguments that are more active during discussion of learning topics in the classroom as well as improving the ability to speak and listen to the students. Furthermore, JPWPKL and PPWS can hold seminar, courses or idea-sharing conferences between School Improvement Specialist Counselors in providing greater detail and widespread use of Six Hats Thought in subject teaching.

This can indirectly increase the level of knowledge, attitudes and practices of Six Hats Thought among teachers as well as the realization of 21st Century Teaching and Learning. School administrators should also play an important role and emphasize the involvement of teachers in courses related to the HOTS teaching method so that teachers can diversify learning delivery methods to students and create a positive and productive learning environment. Next, teachers need to be familiar with every change and development that occurs in the educational curriculum through reading, innovation involvement in education, mass 
media and print media as teachers are the main characters and curriculum interpreters in schools in the realization of an education policy implementation.

\section{Conclusion}

Inferential statistical analysis shows that there is no significant difference in knowledge level, attitude and practice of using Six Hats of Thought in national language teacher of the national school-based on gender while there is significant difference in level of knowledge and practice level of usage of Six Hats of Thought in national language teacher of national school-based on specialization.

However, the level of attitudes towards the use of Six Hats of Thoughts in national language teachers of the national schools based on the specialization shows the results of the reverse. In realizing the goals in line with National Philosophy Education (FPK), one of the aspects that must be emphasized is the aspect of the applied learning method should be appropriate and coincide with the level of understanding and acceptance of the students. This is to ensure that positive student achievement is optimum and shows an impressive improvement from day to day, while strengthening the concept of HOTS.

\section{Conflicts of Interest}

The authors declare no conflicts of interest regarding the publication of this paper.

\section{References}

Abdullah, M. M. N. (2006). Principles and Practices of Teachers in the Teaching of Primary School Education. Master Thesis of Education, Selangor: Faculty of Education, Universiti Kebangsaan Malaysia.

Ahmad, A., \& Mahamod, Z. (2015). The Level of Malay Language Teachers in Secondary Schools in Implementing School Based Assessments Based on Gender, Options and Teaching Places. Journal Malay Language Education, 5, 18-29.

Ahmad, K. (2011). The Effectiveness of Concept Map Methods on Achievement, Attitude, and Understanding of Chronology among Form Four Students. Master Thesis of Education, Selangor: Faculty of Education, Universiti Kebangsaan Malaysia.

Anderson, L. W., \& Krathwohl, D. R. (2001). A Taxonomy for Learning, Teaching, and Assessing: A Revision of Bloom's Taxonomy of Educational Objectives. New York: David Mckay Company, Inc.

Aziz, R. (2011). ICT Knowledge, Attitudes and Skills among Math Teachers in Pahang State Secondary Schools. Master Thesis of Education, Selangor: Faculty of Education, Universiti Kebangsaan Malaysia.

De Bono, E. (1991). Teacher Thinking (5th ed.). London: Tample Smith Ltd.

Hasan, N. H., \& Mahamod, Z. (2016). The Application of High Level Thinking Skills in the Teaching of Malay Language Teachers of the District of Kuala Terengganu. Journal Malay Language Education, 6, 78-90.

Hassan, A. (2009). The Effect of Co-Operative Learning Attitude and Student Achievement of History Subjects. Master Thesis of Education, Selangor: Faculty of Education, Universiti Kebangsaan Malaysia. 
Isa, N. (2015). The Knowledge, Skills of the Implementation and Attitude of Primary School Islamic Teachers towards the Comfort of Learning Styles. Master Thesis of Education, Selangor: Faculty of Education, Universiti Kebangsaan Malaysia.

Ishak, N. N. (2015). Icon Visual Techniques in the Teaching of Writing Simple Sentences of Special Recovery Students. Project Paper of Bachelor of Education, Selangor: Faculty of Education, Universiti Kebangsaan Malaysia.

Isnon, H., \& Jadusah, J. (2017). The Competence of Malay Language Teachers in Applying High Level Thinking Skills in Teaching and Learning. Journal Malay Language Education, 7, 56-66.

Krejcie, R. V., \& Morgan, D. W. (1970). Determining Sample Size for Research Activities. Educational and Psychological Measurement, 30, 607-610. https://doi.org/10.1177/001316447003000308

Lewis, B., \& Smith, R. (2002). The Development of an Electronic Education Portfolio: An Outline for Medical Education Professional. Teaching and Learning in Medicine, 19, 139-147. https://doi.org/10.1080/10401330701332219

Mahamod, Z. (2014). Innovation of Teaching and Learning in Malay Language Education. Tanjung Malim: Publication, Universiti Pendidikan Sultan Idris.

Minirith, F. (2009). A Brilliant MIND: Proven Ways to Increase Your Brain Power. New York: Revell.

Ministry of Education Malaysia (MoE) (2013). Malaysian Education Development Plan 2013-2025. Putrajaya: Teacher Education Division.

Mohamat, H. (2016). The Level of Knowledge, Attitude and Practice of Using I-Think Map among Malay Language Teachers. Project Paper of Bachelor of Education, Faculty of Education.

Mohamed, S. Z. (2006). The Effect of Thinking's Compilation Approaches in the Teaching of Descriptive Essays and Imaginative Essays among Form IV Students. Thesis Dr. Philosophy, Penang: School of Educational Studies, Universiti Sains Malaysia.

Moidunny, K. (2009). The Effectiveness of the National Qualifications Professional Qualification Program (NPQH). Doctor of Philosophy, Selangor: Faculty of Education, Universiti Kebangsaan Malaysia.

Nor, S. Z. M. (2015). Implementation of 5P Concept (Integration, Absorption, Styling, Recovery and Evaluation) in Malay Language Teaching. Master Thesis of Education, Selangor: Faculty of Education, Universiti Kebangsaan Malaysia.

Nordin, A. B. (1995). Affective Assessment. Kajang: Masa Enterprise.

Puteh, S. N. (2012). The Malay Language Teacher's Concern in Critical and Creative Thinking Skills. Journal Malay Language Education, 2, 19-31.

Rahman, S., \& Mahamod, Z. (2016). Creativity in Teaching and Learning. Bangi: Publication Universiti Kebangsaan Malaysia.

Said, M. S., Kadir, M. A., \& Hitam, M. S. A. (2013). Programe Implementation Assessment i-Think: An Introduction. Journal of Educational Leadership, 4, 72-106.

Stegall, D. A. (2011). Professional Learning Communities and Teacher Efficacy: A Correlational Study. Thesis Dissertation, Chapel Hill, NC: University of North Carolina.

Sulaiman, R., Aziz, M., \& Sang, M. S. (2012). Thinking Skills. Selangor: Publications Multimedia.

Tasir, Z., \& Abu, M. S. (2003). Computer Data Analysis SPSS 11.5 for Windows. Kuala Lumpur: VENTON Publishing. 